\title{
Utilisation of Coal in Direct Carbon Fuel Cells
}

\author{
J. Irvine, A. Fuente Cuesta, A. Mottram, C. Jiang, C. Savaniu, and S. Jain \\ School of Chemistry, University of St Andrews, St Andrews, Fife KY16 9ST, UK
}

\begin{abstract}
Hybrid Direct Carbon Fuel Cells merge Solid Oxide Fuel Cell (SOFC) and MCFC technologies, using a solid oxide electrolyte to separate the cathode and anode compartments, while a molten carbonate electrolyte is utilised to extend the anode/electrolyte region. Oxygen is reduced to $\mathrm{O}^{2-}$ ions at the cathode and transported across the solid electrolyte membrane to the anode compartment, where carbon is oxidised to $\mathrm{CO}_{2}$. Molten carbonate could enhance the carbon oxidation in two ways as a fuel carrier or as an electrochemical mediator. The maximum energy density can be achieved by fully oxidising carbon to $\mathrm{CO}_{2}$ offering very high efficiencies. This concept has been demonstrated using a wide range of carbons and carbon-rich fuels such as coal, plastics, carbon colloids, activated carbons and charcoals. In a short stack of 3 cells delivered a maximum power output at $650^{\circ} \mathrm{C}$ of $5.4 \mathrm{~W}$, at over $100 \mathrm{mWcm}^{-2}$. The underlying chemical processes in DCFCs are complex involving a series of catalytic and electrochemical reactions of a complex fuel. Coal and biochars are quite far from pure carbon comprising of high hydrogen content and often significant oxygen, sulphur and nitrogen contents as well as inorganic, ash components. Here we report on the pyrolysis and oxidation reactions and processes that occur in situ and in DCFC relevant conditions. Of key importance is interplay between carbon and its oxides as direct oxidation of carbon to carbon dioxide delivers the ultimate efficiency. There is a change in process above $750^{\circ} \mathrm{C}$ where the reverse Boudouard reaction becomes dominant and our focus is on understanding the lower temperature electrochemical processes.
\end{abstract}

\section{Introduction}

Coal is almost certainly going to be the dominant fuel in coming decades due to its extensive reserves in important energy economies. Indeed, the global reserve-production rate ratio for coal is around three times that of the next-most abundant fossil fuel. Far from reduction of global $\mathrm{CO}_{2}$ emissions, there is likely to be a very significant increase, undermining our climate change efforts, unless more efficient means of carbon conversion are achieved. That is why new clean carbon conversion technologies must be at the forefront of energy technology development. The global abundance of coal, and the present low cost per unit of electricity generated using coal compared with other fossil fuels and uranium, ensures that its usage for electricity generation will continue for many decades[1]. Coal is not a 'clean' fuel, owing to its $\mathrm{CO}_{2}$ and $\mathrm{SO}_{\mathrm{x}} / \mathrm{NO}_{\mathrm{x}}$ emissions upon burning, however emerging technologies may reduce the environmental footprint. For 
example, in situ gasification of coal into $\mathrm{CO}$ produces a more clean-burning fuel. Sequestration of $\mathrm{CO}_{2}$ emissions from coal combustion (carbon capture and storage, CCS) is another option and, as CCS technology develops existing coal-powered stations could be retro-fitted with the appropriate technologies. A very promising alternative method is to produce electricity by oxidising coal electrochemically with oxygen in a direct carbon fuel cell (DCFC).-

A hybrid direct carbon fuel cell merges Solid Oxide Fuel Cell (SOFC) and Molten Carbonate Fuel Cell (MCFC) technologies, using a solid oxide electrolyte to separate the cathode and anode compartments, while molten carbonate electrolyte is utilised to extend the anode/electrolyte region. Oxygen is reduced to $\mathrm{O}^{2-}$ ions at the cathode and transported across the solid electrolyte membrane to the anode compartment, where carbon is oxidised to $\mathrm{CO}_{2}$.

Molten carbonate could enhance the carbon oxidation in two ways as a fuel carrier or as an electrochemical mediator. The ideal anode reaction is the direct electrochemical oxidation of carbon to $\mathrm{CO}_{2}$ The maximum energy density can be achieved by fully oxidising carbon to $\mathrm{CO}_{2}$. This concept avoids the need for $\mathrm{CO}_{2}$ circulation and the protection of the cathode from molten carbonate, and allows the use of materials already developed for SOFC applications. In ongoing studies at St Andrews this concept has been demonstrated using a wide range of carbons and carbon-rich fuels such as carbon black, pyrolysed medium density fiberboard (PMDF) and in tubular cells [2,3]. The electrochemistry of the direct oxidation of solid carbon in the HDCFC with solid oxide and molten carbonate binary electrolyte was also recently investigated using a planar test cell. [4,5] The carbon/carbonate slurry increased the active reaction zone from a twodimensional $\mathrm{Ni} / \mathrm{YSZ}$ anode to a three-dimensional slurry and significantly enhanced carbon oxidation. The electrochemical oxidation in the anode compartment is quite selective to $\mathrm{CO}_{2}$ formation, but the final distribution of products is dominated by the equilibrium of the Boudouard reaction, which increasingly yields $\mathrm{CO}$ as temperature increases. Gur circumvented the difficulty of attaining solid fuel-to-anode contact by fluidising the carbon in flowing $\mathrm{CO}_{2}$, which generates $\mathrm{CO}$ in situ via the Boudouard reaction [6].

In this design, oxygen ions are produced at an SOFC cathode such as lanthanum doped strontium manganite $\left(\left(\mathrm{La}_{0.8} \mathrm{Sr}_{0.2}\right)_{0.95} \mathrm{MnO}_{3-\delta}, \mathrm{LSM}\right)$, and transported by the YSZ electrolyte to the anode chamber, where a lithium-potassium carbonate having a melting temperature of $500{ }^{\circ} \mathrm{C}$, which is the lowest in the binary carbonate systems, is used as the second electrolyte. Intensive investigations have been conducted to understand the fundamentals of the HDCFC concept, and optimise their performance. The advantage of this cell design is that carbon is oxidised in the alumina chamber, which is sealed using the solid oxide fuel cell. The atmosphere of the anode chamber can be controlled by purging with various gases. Inert gas, such as argon or nitrogen, not only prevents the direct oxidation of carbon but also purges the reaction products from the cell.

Extensive research has been made to optimise the cell performance based on the carbonate content, the solid oxide cell design, electrode or electrolyte materials, the nature of the purge gas, or the flow rates of gases employed at the anode and the cathode during operation 


\section{Results}

A stack unit was designed as show in the schematic in figure 1 (a). Each of the cell units was assembled in the machined manifolds and individual gas lines were fitted to each cell which could also be used for current collection. Figure 1 (b) shows how the framework was assembled in the oven and the measures taken to ensure the there was no risk of short circuiting between the stack components.

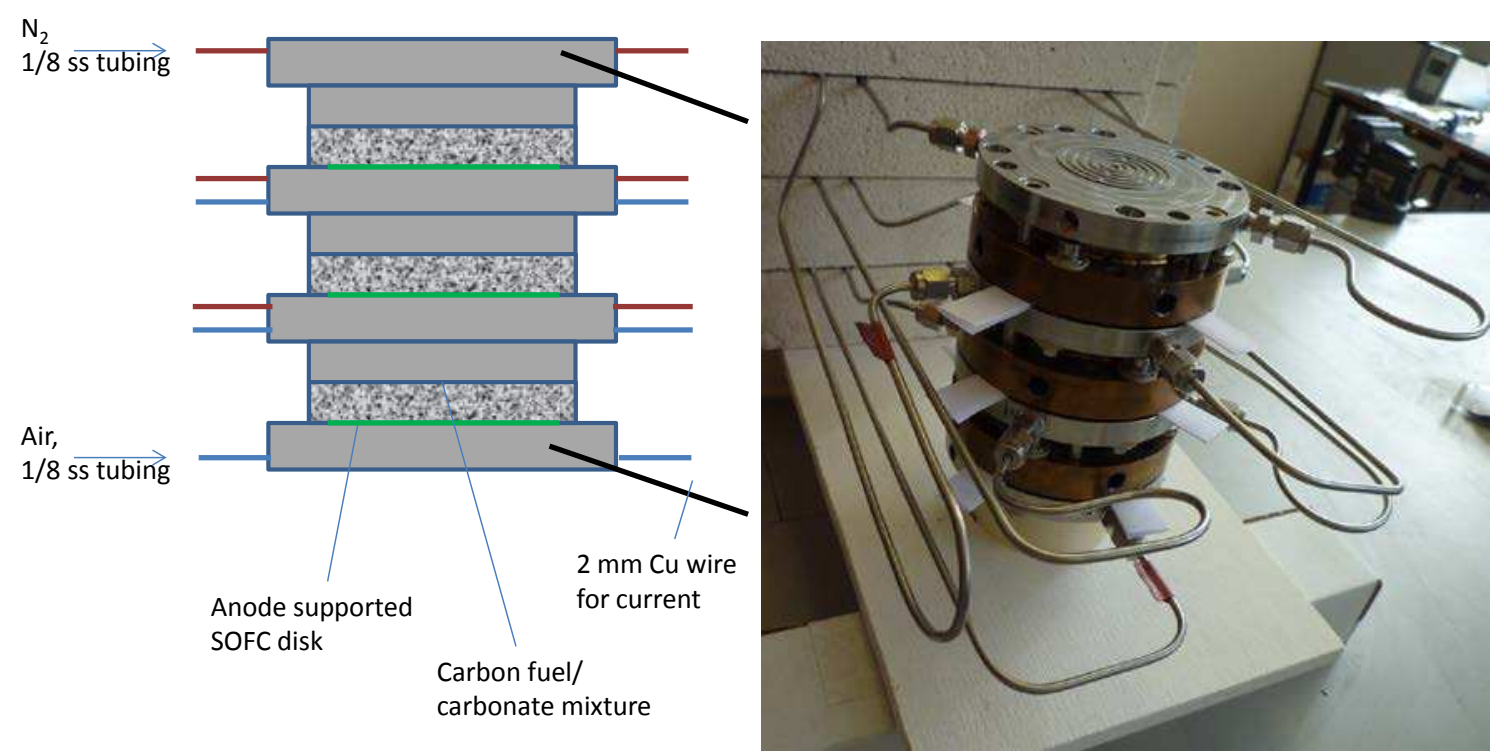

Figure 1. (a) schematic of short cell assembly showing individual components and (b) photo of cell assemble with all gas connections as seen in the furnace prior to testing.

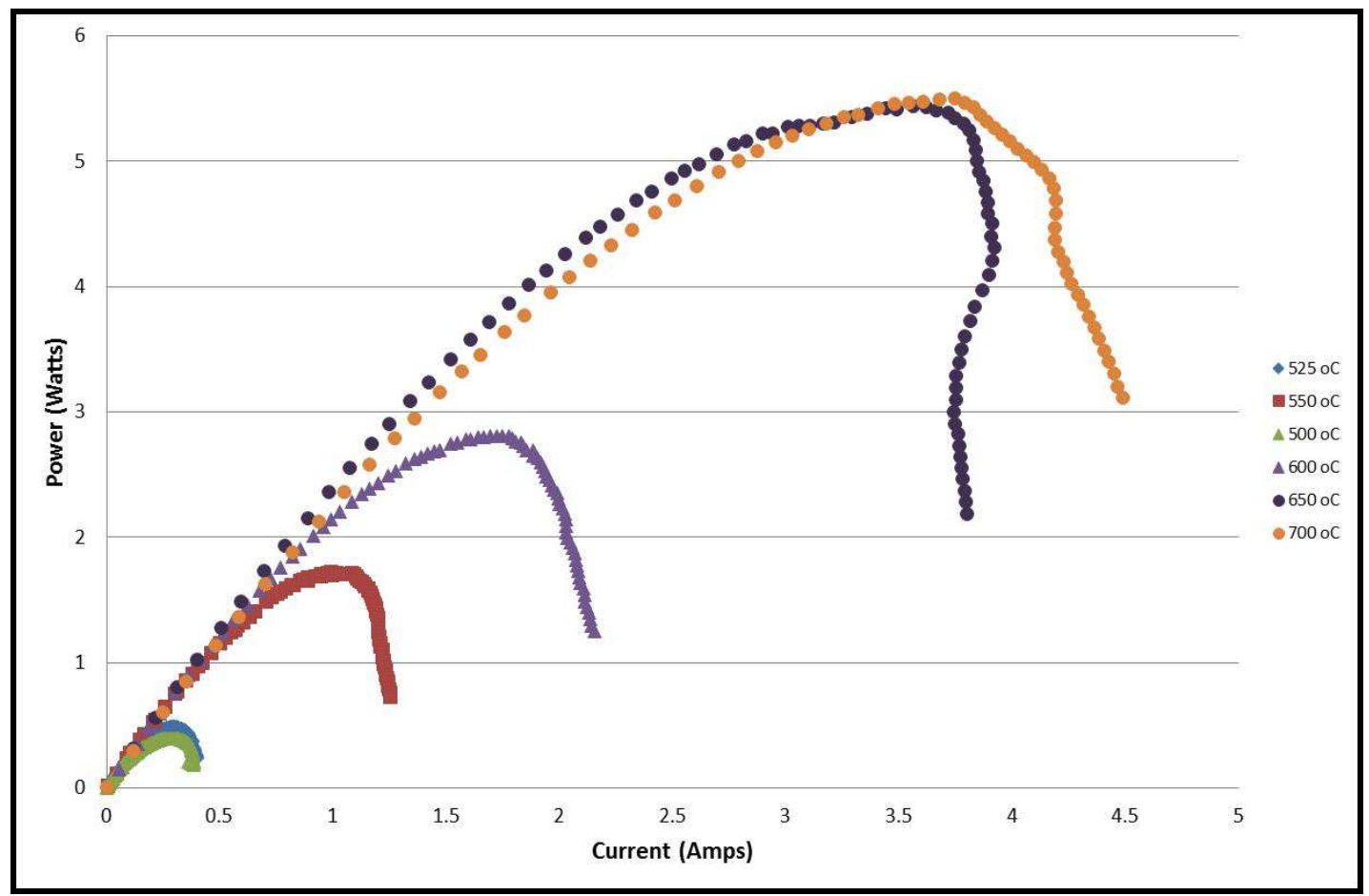

Figure 2. Graph showing the performance of the short stack direct carbon fuel cell as a function of temperature. 
The unit was assembled using Bituminous coal and carbonate eutectic mixture in a $5: 1$ ratio, and heated at a rate of $0.5^{\circ} \mathrm{C} / \mathrm{min}$ allowing the eutectic mixture to melt gradually up to $450^{\circ} \mathrm{C}$ with gas flows of air on the cathode side at $20 \mathrm{ml} / \mathrm{min}$ and $\mathrm{N}_{2}$ on the anode side at $20 \mathrm{ml} / \mathrm{min}$, there after the rate of heating was $1^{\circ} \mathrm{C} / \mathrm{min}$ and the gases adjusted to air on the cathode side at $10 \mathrm{ml} / \mathrm{min}$ and $\mathrm{N}_{2}$ on the anode side at $200 \mathrm{ml} / \mathrm{min}$. Measurements were taken at $500,525,550^{\circ} \mathrm{C}$ and the $50^{\circ} \mathrm{C}$ up to $700^{\circ} \mathrm{C}$. The current vs power data taken at each of the temperatures are shown in figure 2 . At $650^{\circ} \mathrm{C}$, the maximum power measured was $5.4 \mathrm{~W}$. At $700^{\circ} \mathrm{C}$ there was no significant difference in the power measured, however higher currents were achieved

\section{Acknowledgments}

We thank the Research fund for coal and steel for supporting this research, Grant Agreement Number: RFCR CT-2011-00004

\section{References}

1. EU Energy Policy Data, SEC 2007,WEO 2006 COECD/IEA 2006European Commission "EU Energy Roadmap 2050", COM(2011) 885/2, 2011., http://eurlex.europa.eu, : Brussels,

2. Y. Nabae, K. D. Pointon and J. T. S. Irvine, Energy Environ. Sci., 2008, 1, $148-$ 155.

3. S. L. Jain, J. B. Lakeman, K. D. Pointon, R. Marshall and J. T. S. Irvine, Energy Environ. Sci., 2009, 2, 687.

4. Y. Nabae, K. D. Pointon and J. T. S. Irvine, J. Electrochem. Soc., 2009, 156, B716-B720.

5. C. R. Jiang and J. T. S. Irvine, J. Power Sources, 2011, 196, 7318-7322.

6. C. Lee, S. Li, R. E. Mitchell and T. M. Gür, Electrochem. Solid State Lett., 2008, 11, B20-B23 